\title{
Children's Acquisition of Communicative Competence and Discussion on Awakening and Developing Students' Communicative Competence in University English Teaching
}

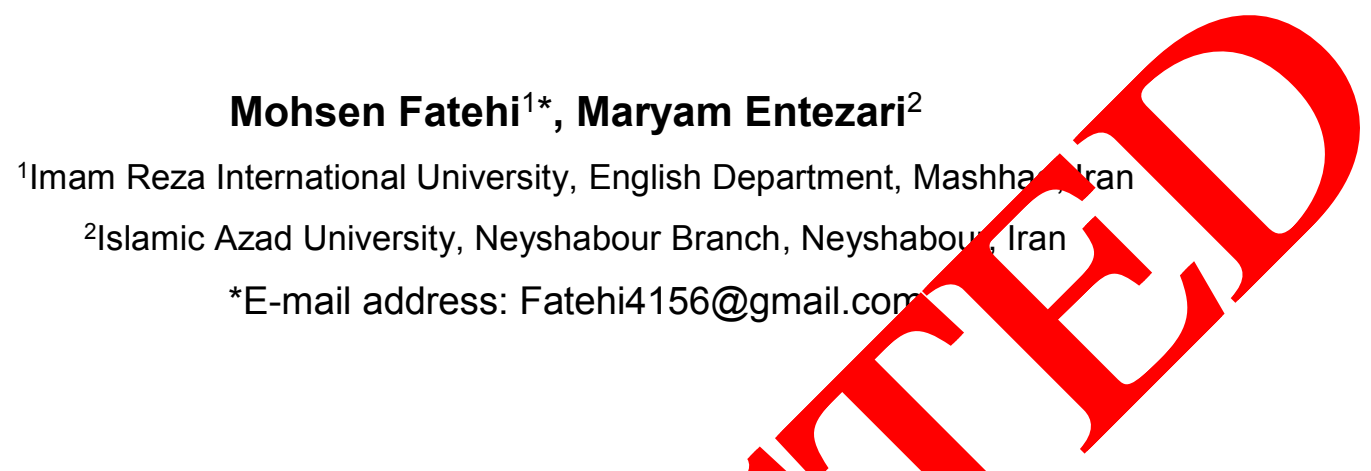

\section{ABSTRACT}

What plays an important role in language teaching a This paper tries to explore the children's acquisition of spread and development of English around the world improved methods to develop university students' Englis

This paper also dissects the inevitability and viabil Tearning is Co anicative competence. mmunicative competence and yet with the $d$ its increas d use in Iran, research about vel has be ome of great importance. competence in University English Teaching (U) also debates the advantages and challenges of Communicative Language Teaching (CLT) for ET. tionnaire is used to determine students' understanding of the term communicative compete

Keywords: communicative cor beteno acquis on; children; English language teaching; communicative competence; untvo

\section{INTRODUC}

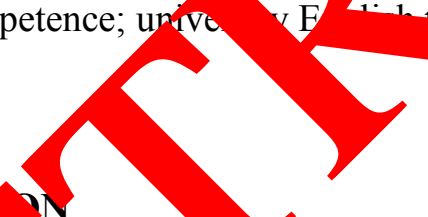

As $\mathrm{H}_{5}$ poi a cou native speakers who could produce any and all of the grammatical sentences of a ouage suld be institutionalized if they tried to do so. Communicative comp invol kn owing not only the language code, but also what to say to whom, and hoy to sa it appro priately in any given situation. It deals with the social and cultural know so presumed to have to enable them to use and interpret linguistic forms.

c municative competence extends to both knowledge and expectation of who may or may not $s_{1}$ in certain settings, when to speak and when to remain silent, whom one may speak to, how one may talk to persons of different statuses and roles, how to ask for and give information, how to request, how to give commands, etc. in short, everything involving the use of language and other communicative dimensions in particular social settings. It needs to be pointed out that cross-cultural differences can and do produce conflicts or inhibit communication. For example, certain American Indian groups are accustomed to waiting several minutes in silence before responding to a question or taking a turn in conversation, while the native English speakers they may be talking to have very short time frames for responses or conversational turn-taking, and find silences embarrassing. In this way, the 
concept of communicative competence must be embedded in the notion of cultural competence or the total set of knowledge and skills which speakers bring into a situation. In fact, all aspects of culture are relevant to communication, but those that have the most direct bearing on communicative forms and processes are the social structure, the values and attitudes held about language and ways of speaking, the network of conceptual categories which results from shared experiences, and the ways knowledge and skills are transmitted from one generation to the next, and to new members of the group. All in all, communicative competence refers to knowledge and skills for contextually appropriate use and interpretation of language in a community; it refers to the communicative knowledge and skills shomed by the group, although these reside variably in its individual members. The shared y andiv 1 nature of competence reflects the nature of language itself.

\section{CHILDREN'S ACQUISITION OF COMMUNICATIVE CON 'ETE' SE}

All human infants are born with the capacity to develop $y$ atterned 1 for appropriate language use from whatever input is provided within their na w eech com aity. Children are essentially participant-observers of communication le ing inductively developing the rules of their speech community through process observa and interaction. So input is very important in the process of acquiring communicative cympetence. Sources of input for children vary depending on cultural and so al factors. Fpr example, mother's talk is often assumed to be universally the most important rce of ear y input, but wealthier social classes in many cultures delegate most caretaking to. servants, while in some other cultures, older siblings have major childrear sonsibilities.

One more thing need to be pointed ou is ian children have limited input from any source, communicative develonment $\mathrm{m}$ indeed be retarded, though this may be overcome in later childhood.

\subsection{Social interaction}

Although langy a quisition generally considered to be primarily a cognitive process, it is clearl socia cess as well, and must take place within the context of social interaction. Our ollowing disc on will focus on the interaction between adult and children. Halliday clai s that ildren lezrn the meaning of language because of the systematic relation between what hear an what is going on around them. While all language is learned in the pro of ial inaction, different linguistic forms are considered 'typical' or app opriat between aults and children. Much of the earlier research on acquisition in the prou of speech. Tere are speech communities where mimicry is very common, and considered the most app ate form of social interaction between adults and young children. There are also influences which children themselves have on adult communicative behavior. According to Von Raffler-Engel and Rea, much of the interaction between adults and children is nonverbal, or paralinguistic; children often confirm understanding with facial expressions or head nods, which suggest the need to expand the scope of interaction. 


\subsection{Language and enculturation}

We must admit that language is mainly learnt rather than inherited. Language learning for children is an integral part of their enculturation from three perspectives: 1) language is part of culture, and thus part of the body of knowledge, attitudes, and skills which is transmitted from one generation to the next; 2) language is a primary medium through which other aspects of culture are transmitted; 3) language is a tool which children may use to explore the social environment and establish their status and role-relationships within it. Hall distinguishes three kinds of learning, which are formal learning, informal learnino and technical learning.

Formal learning takes place through precept and admonition, and aspects of culture which are not to be questioned.

Informal learning takes place primarily through nonverbal channe's of comm icati on, with the chief agent a model used for imitation. Pragmatic comp ance jolso a informally.

Technical learning is at an explicitly formulated, conscio s level, a incly aes all that children find out in school about the grammar they have alrea ay vuired into ally; rules are explained by adults and deviations usually correctea witho emotional and moral involvement. Written language skills are most likely ou taught h technical mode, and more advanced oral rhetorical skills may also be dev oped at this level. All cultures make use of all three of these modes of enculturation to som degree, but formal learning tends to be prominent where authority in the family is strictly or ed in a hi rarchy, and where there is a great respect for tradition. On the other band, child nore likely to be taught on a technical level in a knowledge- oriented soc all channels of communication, and in all dim nsif is ach channel.

In short, the role of language in encu ration is both for personal growth and for socialization. From the perspect ve the con nunity as a whole, creating conformity and effecting transmission of the ture are the rimary functions of language learning, i.e. successful socialization.

\subsection{Teaching englis' in}

Nowaday Enclish, as a Mternational language is widely used in communication between peo and untries. The English language has spread and developed worldwide, which is a fac at cann be ignored. In Iran, as the main foreign language taught and employ com nica on with foreigners, the use of English has dramatically increased, esp rally the red years. However, English Language Teaching (ELT) in Iran has not afro th ${ }^{2}$ matiofal teaching model whereby students learn English just to pass exams and teacher scture mainly to help students achieve this goal. The direct consequence is that students to communicate effectively with others in English. Clearly, students ${ }^{\text {ee }}$ overall skills cannot be enriched, especially for students at university level. Teachers in English faculties do a better job and that is to set an ultimate goal in mastery of all four skills with an emphasis on listening and speaking so that students in their future work and social interactions will be able to exchange information effectively through both spoken and written channels, and at the same time they will be able to boost their ability to study independently and improve their cultural quality so as to meet their demands. It goes without saying that this method cannot be widely implemented as expected. Also what can be done in order to develop university students' communicative competence remains number one priority. 


\subsection{The notion of communicative competence and its awakening}

One of the earliest concepts of communicative competence was introduced by Hymes (1972). He believed that the ability to communicate properly should be cultivated in language teaching. Students should learn how to use a language in their daily communication in order to demonstrate their mastery of a language. Hymese (1972) theory of communicative competence has been widely acknowledged and accepted by English educators and scholars (Canale \& Swain, 1980; Kunschak, 2004; McKay, 2002). As the concept of "communicative competence" is being further developed, different language skills such as limmistic, sociolinguistic, discourse, strategic and pragmatic competences are receiving increasing (Davies, 2005; Hedge, 2000). Kramsch (2006, p.36) states that "language "ning, as acquisition of communicative competence, is now defined as the exprescion, rpretati and negotiation of meaning between two interlocutors or between a text $/ 1 \mathrm{~d}$ its reaa

It is believed that one of the main goals of both ELT and in Irap owads is to velop students' communicative competence, as more students w' Eng as a communicating tool after graduation. If students can use the F iglish kn ledge, skills and cultural aspects they have learned to communicate wit a ple of c crent cultural backgrounds in real language contexts, they are then using glish commanication tool.

\subsection{The inevitability and viability of awakening $s$ dents communifative competence}

Generally speaking, students that their majo is Englis are a minority at Iranian universities. But more students will use Eprlish in fu crs such as business, law, and journalism. English will be used as a tool to nunicate or negotiate with different people after their graduation. In other words, the po ular sy english worldwide paves the ground for a clear rationale to reform ELT in-Iran, get a of exam-oriented education, and to focus on developing students' listening a a s s king sk '/s, so they learn to communicate effectively with others. Improving unive En 'lish teachers' abilities and qualifications necessarily mean improving universit ud com nicative skills. Teachers should participate in designing syllabi and b ware of th biectives of UET. Many Iranians who have M.A and $\mathrm{Ph} . \mathrm{D}$. degrees relate to English guage/literature or Teaching English to Speakers of Other Languages T,SOL) vome valuable resources for UET. Many such teachers are overseas gradures and are bo spirited and better perceptive of the English language and culture. The re, th rospective and reformative consciousness of such teachers gives UET new chances a servor. Iniversity facilities and resources are also gradually improving compar with pas decade. Moreover, UET in Iran today is more student-centered. Tea ners o mostly $l$ as igniters in the process of communicative language teaching (CLT). As 'ms conof, p.38) have pointed out, "[teachers] set up the conditions under which learne arn to learn. The teacher is to be a "guide on the side, rather than sage on the stage". We shoul $o g$ be cognizant of the different attitudes of teachers and students toward English teaching and learning. It cannot be ignored that many university students still do not have clear rationales for learning English, or they learn English for the sheer sake of passing exams. Thus, it is not an easy job to implement a plan to develop university students' communicative competence. 


\subsection{The merits of awakening students communicative competence}

Students develop their listening skill and also gain confidence during the process of communication at the same time while developing their speaking abilities and increasing their vocabulary level. It is vivid that an English context is automatically created during various activities when implementing CLT while English is used as the tool for students to communicate with each other. The English context can help students cultivate their sense of the language, and create a milieu where students can improve their English ability. CLT provides students a chance to speak and share ideas in a rather relaxing way. Thus ctudents become the leading characters in the classroom, and their initiative and motivat on aro th enhanced. If one worry about the lack of English written work that may ip de studen English study, can rest assured because CLT not only focuses on demelop studen listening and speaking skills of English, but also reading and writ ing skills. T an introduce new teaching methods, creating a miscellaneous teaching $p$ ess. J chers a use different resources to help students awaken their communicatiy sk which another illustration of the diversity of the teaching method. For exam ie, Engli teach rs can use pictures to promote group discussions, subsequently ho students aderstand the informational and cultural background of different topics. Fame on also be used to help students learn vocabulary and practice their writing ski1 ${ }^{1}$. w ore to tho int, teachers can help students create an English context when teaching gra hmar and Wester/culture. They can ask students questions. During group discussions, stude both pract'te their spoken English and learn about different cultures. Grammar can also be acticed d ring this process. However, the challenges of CLT cannot be overlocked and y aditional ELT model in Iran remains a big challenge.

\subsection{The challenges of developing students ch imunicative competence}

The first and for most aditi hal limitation to developing students' communicative competence is the inappro te actur. etween teachers and students. Teachers simply spend much time lectur while st. ts, take copious notes and seldom participate in class. The relatively fatigu ig based tea sing method makes students unenthusiastic to freely participate in clas ro m dis sions. Therefore, in Iranian universities the communicative teaching approch still cannot eye-catchingly witnessed in action. It seems that teachers and student ave led to understand the benefits of enhancing the communicative competence in proces of ELT. We should also take into account that the number of student Engh las os is way greater than expected (generally around 50 to 60 in one clas . Th efore, cater numbers of students do not have enough opportunity to com. nic ach other in English. Students' lack of initiative may also play role in the effecti ess of teaching.

Tho ond hindrance to implementing CLT is the method of evaluating UET. Currently, he evaluation reforms pay more attention to developing students' integrated ability. Students who take the oral English proficiency tests are mostly higher-intermediate students, who comprise a small portion of the university population. Although some universities pay more attention to developing students' communicative competence, the traditional assessing system is still deep-rooted, and the shift between "accuracy" and "fluency" is still worth considering if this teaching method is to be more vastly implemented.

Yet another challenge of CLT may be related to the students. The lack of input and output of English leads to a lack in students' reading vocabulary skill, which might make it 
difficult to successfully implement this teaching method. Furthermore, different attitudes toward learning English may also hinder students' learning. Thus, it is necessary that teachers and students create a good balance between English teaching and learning, and allowing the communicative competence to gradually soak in.

\subsection{Questionnaire}

\section{A) Questionnaire layout}

A questionnaire was exercised to explore university students' understanding orCD $\mathrm{d}$ their need to learn English at university. Altogether 150 participants nswered questionnaire; 97 respondents were lower-intermediate students and 53 e high intermediate. Both groups were asked to answer the questionnaire at inter als of tho ass.

\section{B) Analysis}

Table 1. Students opinions about communicative conce and $\mathrm{C}$

\begin{tabular}{|c|c|c|c|c|c|}
\hline Questions & Options & Intermes & Percen & $\begin{array}{l}\text { dvanced } \\
\text { tudents }\end{array}$ & Percent \\
\hline $\begin{array}{l}\text { Do you know what } \\
\text { "Communicative } \\
\text { competence" } \\
\text { means? }\end{array}$ & Yes & & $3 / .11$ & 25 & 47.16 \\
\hline $\begin{array}{l}\text { What area is } \\
\text { communicative } \\
\text { competence mostly } \\
\text { concerned about? }\end{array}$ & $\begin{array}{l}\text { Listening } \\
\text { Speaking }\end{array}$ & 3 & $\begin{array}{c}14.43 \\
46.39 \\
4.12 \\
3.09\end{array}$ & $\begin{array}{c}5 \\
40 \\
5 \\
3\end{array}$ & $\begin{array}{l}9.43 \\
75.47 \\
9.43 \\
5.66\end{array}$ \\
\hline $\begin{array}{l}\text { Which skill } \\
\text { matters for you? }\end{array}$ & & $\begin{array}{c}30 \\
51 \\
3 \\
2 \\
\end{array}$ & $\begin{array}{c}30.92 \\
52.57 \\
3.09 \\
2.06 \\
\end{array}$ & $\begin{array}{c}15 \\
30 \\
6 \\
2 \\
\end{array}$ & $\begin{array}{c}28.30 \\
56.60 \\
11.32 \\
3.77 \\
\end{array}$ \\
\hline English & $\begin{array}{l}\text { No } \\
\text { Neutral }\end{array}$ & $\begin{array}{c}55 \\
35 \\
7\end{array}$ & $\begin{array}{c}56.70 \\
36.08 \\
7.21\end{array}$ & $\begin{array}{c}35 \\
15 \\
3\end{array}$ & $\begin{array}{c}66.03 \\
28.30 \\
5.66\end{array}$ \\
\hline $\begin{array}{l}\text { yo } \\
\text { univ }\end{array}$ & $\begin{array}{c}\text { Yes } \\
\text { No } \\
\text { Neutral }\end{array}$ & $\begin{array}{c}65 \\
25 \\
7\end{array}$ & $\begin{array}{c}67.01 \\
25.77 \\
7.21\end{array}$ & $\begin{array}{c}20 \\
30 \\
3\end{array}$ & $\begin{array}{c}47.16 \\
56.60 \\
5.66\end{array}$ \\
\hline
\end{tabular}

Regarding the first question, $37.11 \%$ of students at the lower-intermediate level the term "communicative competence", while only $47.16 \%$ of students at the higher-intermediate level knew this term. This term is not very well-known among these students.

It is for sure necessary that the purpose and benefits of implementing CLT should be explained to students. Question two is designed to discover students' thoughts about the area that they think communicative competence is mostly concerned about. Although not too many students had heard the term "communicative competence", many seemed to understand what 
communicative competence emphasizes. Many of the students at both levels believed that the communicative teaching approach focuses on speaking skills (because students are exposed to various communicative activities, such as group discussions, role playing, and debating). Question three is designed to discover students' thoughts about the four basic skills in English learning. Not surprisingly, students at both levels believed speaking is the most important skill $-52.57 \%$ of the lower-intermediate students and $56.60 \%$ of the higher-intermediate students chose this skill. The listening skill was chosen by around $30 \%$ of the students in both levels. Few students regarded reading or writing as the most significant skill when learning English. Also, few students chose two skills altogether because they might beliom for example, that speaking and listening skills inherently go together. Generally peakin. s students have to go to interviews or communicate with various people af graduati speaking seems to be the most important skill for them However, tho co onents communicative competence, which are linguistic, sociolinguistic, dis ourse anc rate sic competence (Dai \& Chen, 2008; Hedge, 2000), and the purpose f CL are tâ more complicated. The last question was meant to determine lower-leve tut and her-level students' satisfaction and expectations with UET. Among the rower-in redia students, $56.70 \%$ thought positively about learning English at uni e and be ed that UET satisfied them. However, many higher-intermediate studer felt UET aidn't meet their expectations. Their reasons were that they did not lea nul thin $n$ that their English ability had not improved, there was not enough opp tunity to practice English in class, class is boring, and they did not like the teaching method.

\subsection{Implications}

From the questionnaire, we can see th $\mathrm{g}$ atm number of students still hold great desires for learning English at university; il proving speaking skills is one of the most important things for students. IS lge (20 0, p. 71) notes, "communicative language teaching sets out to involve 1 ers $j$ nurpose ul tasks which are embedded in meaningful contexts and which reflec and an it is used authentically in the world outside the classroom" Therefore, believe that CLT is useful for creating a learning environment and sho a nplement, in more Iranian universities. Also, curriculum design and class size sh ve be ac to better fit this teaching method. Developing students' communicative competence s ad help students more easily use their English. Their pragmatic co neten can also be developed through cultivating their English ability using this teaching od, all ying students to learn English in a more practical way. Scovel (2006 poi out hat "[communicative competence] does not neglect grammatical con eteno it simp ouilds upon it by emphasizing that other skills need to be acquired if one to of fluent and accurate speaker of another language". Therefore, it is also necess. to have a post-communicative model when implementing CLT. ELT in Iran needs to be disc by both teachers and students so they might gain a proper understanding of the aim and how ELT can be further developed and reformed. According to Bygate (2001, 1728), teaching English is not simply providing "the opportunity for learners to use language in order to communicate meaning without focusing on accuracy" and "a distinct methodology and syllabus may be needed". 


\section{CONCLUSION}

This paper talked about the acquisition of communicative competence. The most important thing is communication, i.e. through early imitation or repetition, social interaction and enculturation, children can obtain the rules of speaking in their speech community, thus become a member of their society.

The use of UET will produce new English speakers, especially in EFL countries such as Iran. We should also understand that it is necessary for UET to have reasonable aims and requirements, and that it is necessary to improve current teaching methods to imnrove students' oral English proficiency. Awakening and developing students corimunic e competence is mandatory for ELT in Iranian universities, and should be 2 riority wh teaching and learning English today. University English teachers should be rmo ith amp knowledge to guide students in the process of learning English. Therefo, e, it is pro sing to implement integrated skills into English teaching when promot the mmu ative teaching approach. We should look at CLT as a task within the gg mewor of Therefore, from the discussions above, it will be suitable to $\mathrm{j}$ iplement con municative language teaching approach to help university students in a vprove th English skills way more efficiently.

\section{References}

[1] Brumfit, C. (1979). „Communicative ${ }^{e e}$ Language In: C. J. Brumfit, \& K. Johnson (eds). 1 mmunicative Approach to Language Teaching. Oxford: Oxford University Pre s, 1

[2] Bygate, M. (2001). Speaking. Ronal \& D. Nunan. The Cambridge Guide to Teaching English to Speake sof $\mathrm{c}$ her Lan ges. Cambridge: Cambridge University Press, 14-20.

[3] Byram, M. (1988). "ost-Com, icative" Language Teaching. British Journal of Language Teachi g, (1), 3-6.

[4] Canale, M. \& Swain. Theoretical Bases of Communicative Approaches to Second La guage Teaching nd Testing. Applied Linguistics, 1, 1-47.

[5] Chen, in. \& AU X. P. (2006). Towards the Acceptability of China English at Home and Abroad. "angin English, 13 (2), 231-240.

[6] China linistry Lducation. (2007). College English Curriculum Requirements. Beijing: cunation Press.

[7] Da, X., \& Chen Z. L. (2008). Contemporary English Language Teaching: Theory and Practi Hefei: University of Science and Technology of China Press.

[8] Davies, A. (2005). A Glossary of Applied Linguistics. Edinburgh: Edinburgh University Press.

[9] Hedge, T. (2000). Teaching and Learning in the Language Classroom. Oxford: Oxford University Press.

[10]Hymes, D. (1972). On Communicative Competence. In: J. B. Pride, \& J. Holmes. (eds.) Sociolinguistics. Penguin: Harmondsworth, 269-293. 
[11] Kramsch, C. (2006). The Uses of Communicative Competence in a Global World. Review of Applied Linguistics in China, 2, 30-50.

[12]Kunschak, C. (2004). Language Variation in Foreign Language Teaching: On the Road to Communicative Competence. Frankfurt/Main: Peter Lang Publishing.

[13]McArthur, T. (2002). Oxford Guide to World English. Oxford: Oxford University Press.

[14] McKay, S. L. (2002). Teaching English as an International Language: Rethinking Goals and Approaches. Oxford: OxfordUniversity Press.

[15] Scovel, T. (2006). Learning Communicative Competence: Insights from Psycholinguistics and SLA. Review of Applied Linguistics in China, 2, 7-2

[16] Yang W.Y., \& Fang F. (2008). Optimization of Multimedia English Te hing Contex Creation. International Education Studies, 1 (4), 136-142. [17] Hall B. and W.

Gudykunst. 1986. The Intergroup Theory of Second Language A ty. $J_{O}$ alof Language and Social Psychology. 5: 291-302.

[17]Halliday, M. A. K. 1975. Learning How to Mean: Explor Language. London: Arnold.

[18]Hymes, D. 1971. Competence and performance in nustic theor R. Huxley \& E. Ingram (eds.) Language Acquisition: Models an Methods. Londoy. Academic Press.

[19] Jean Stilwell Peccei. 2000. Child Language. Be g: Foreign Language Teaching and Research Press.

[20] Saville-Troike, Muriel. 1982. The Ethnd of Communication. Oxford: Basil Blackwell Publisher Ltd.

[21] Wolfson, Nessa. 1989. Perspe Socio nguistics and TESOL. New York: Newbury House Publishers.

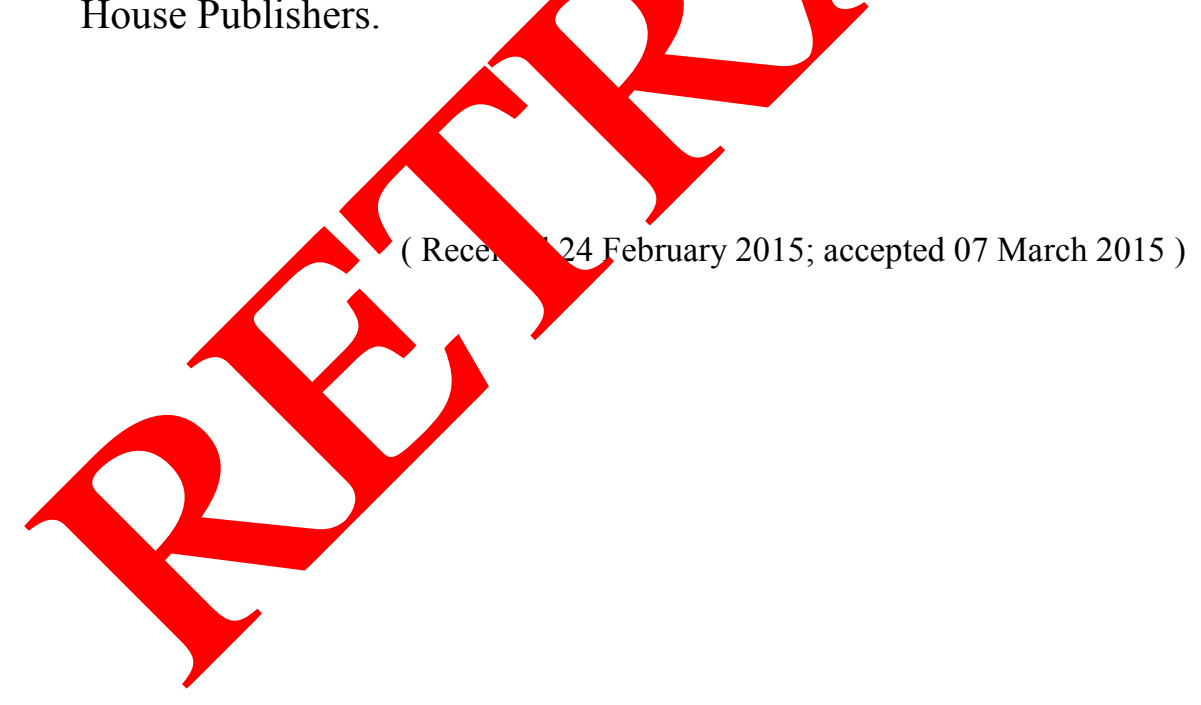

